Будняк Любов, Добровольська Елла, Добровольський Микола. Особливості аналізу оборотних активів на макрорівні в умовах сьогодення. Інститут бухгалтерського обліку, контроль та аналіз в умовах глобалізації. 2019. Випуск 1-2. С. 105-117.

DOl: https://doi.org/10.35774/ibo2019.01.105

УДК 303.7:330.14:336.663

JEL Classification B4, C8, G12, 016

\author{
Будняк Любов \\ канд. екон. наук, доцент \\ кафедра фінансів, банківської справи та страхування \\ Подільський державний аграрно-технічний університет \\ Кам'янець-Подільський, Україна \\ E-mail: budnyakluba@gmail.com \\ Добровольська Елла \\ канд. екон. наук, доцент \\ кафедра економіки підприємництва, торгівлі та біржової діяльності \\ Подільський державний аграрно-технічний університет \\ Кам'янець-Подільський, Україна \\ E-mail: dobrovolskaella@gmail.com \\ Добровольський Микола \\ студент магістеріуму \\ спеціальності фінанси, банківська справа та страхування \\ Подільський державний аграрно-технічний університет \\ Кам'янець-Подільський, Україна \\ E-mail: budnyakluba@gmail.com

\section{ОСОБЛИВОСТІ АНАЛІЗУ ОБОРОТНИХ АКТИВІВ НА МАКРОРІВНІ В УМОВАХ СЬОГОДЕННЯ}

\footnotetext{
Анотація

В умовах нестабільної економіки важливим моментом, для здійснення безперервного виробничого процесу, $є$ своєчасне забезпечення його сировиною, матеріалами, високої якості, в необхідному обсязі, за доступною ціною тощо. Всі ці моменти стосуються оборотного капіталу, оборотних засобів, оборотних активів. Тому їх аналіз, сприяє вирішенню багатьох питань пов'язаних з ефрективністю виробництва, використання ресурсів, витрат тощо.

В даній статті акцентовано увагу на процедурі аналізу оборотних активів на рівні Хмельницької області. Зазначено методичні етапи та запропоновано систему показників, які є доречними в умовах сьогодення.

Для розкриття вище зазначеного використовувалися різноманітні загальнонаукові, статистичні та конкретно економічні методи і прийоми. Так, для дослідження динамічного ряду випуску продукиії, оборотних активів та джерел їх формування задіяні прийоми рядів динаміки, відносних величин, порівняння, аналізу і синтезу тощо. За допомогою грасрічного методу вдалося проаналізувати структуру випуску продукції, джерел формування оборотних активів та вияснити домінанти в даному питанні. Прийоми елімінування дозволили вивчити причинно-наслідкові зв'язки і залежності між фракторами формування та ефективності використання оборотних активів. Скориставшись способами перетворення детермінованих кратних моделей вдалося створити нову модель, з новими чинниками, і з іншого боку підійти до аналізу результативної ознаки.

Проведені дослідження дозволяють зробити висновок, що аналіз оборотних активів на макрорівні має свої специфічні особливості. Вони скоріше за все стосуються не методики, а системи показників. Деякі ми порахувати не можемо, у зв'язку із браком інфоормації або вона пов'язана із комериійною таємницею, а деякі ми
} 
пропонуємо використати. Хоча науковці, які з фрінансової точки зору розкривають дане питання, їх не пропонують. Це стосується показників фондовіддачі і фондомісткості.

Ключові слова: оборотні активи, джерела формування, ефективність використання, фракторний аналіз, причинно-наслідкові зв'язки, детерміновані моделі.

\section{Вступ.}

Більша частина підприємств, маючи у своєму розпорядженні певну кількість матеріальних і фінансових ресурсів, вкладаючи їх у виробництво не отримують бажаного ефекту. Це відбувається тому, що вони не вміють управляти ними. Процедура управління оборотними активами щільно пов'язана і по суті справи випливає з проведеного аналізу. Останній дає можливість встановити наявність, вивчити структуру оборотних активів, співвідношення, які сфрормувалися між окремими їі частинами, джерела їх формування та ефективність використання. Особливо важливим, при цьому, виступає питання причин (факторів), що зумовили не виконання планових завдань.

\section{Аналіз останніх досліджень і публікацій.}

Питання аналізу оборотних активів розкривалися у працях багатьох науковців. Одні з них Причепа І. В., Руда Л. П. [1], Нікіфорова Л. О. [2], Дробишева О. О. [3], Лаврова О. В. [4], Філімоненков О. С. [5] та інші ґрунтувалися на економічному бачені даної проблеми, інші фінансовому. До останніх належать: Купріна Н.М., Черненко І.О.[6], Купріянова Л.М. [7], Рубаха М. В. [8], Шутько Г.М., Рахімова Р. Р. [9], Власова Н. О., Чорна М. В., Михайлова О. В. [10], Соляник Л. Г., Дубєй Ю. В. [11] та інші. Виходячи з цього в науковій літературі зустрічаємо два підходи, щодо дослідження даного питання. Причому вони різняться не процедурними моментами аналізу даного процесу, а показниками і складовими оборотних активів, які необхідно дослідити.

Так, прихильники економічного розгляду даного питання вважають, що варто акцентувати свою увагу на матеріальній частині оборотних активів. При цьому система показників включатиме коефріцієнти оборотності, завантаження і тривалості обороту всієї сукупності оборотних активів та їх матеріальної частини, в т. ч. запасів. Деякі з них пропонують додати до вище зазначених показників систему показників матеріалоємності і матеріаловіддачі [12], а деякі - фондовіддачі і фондоємності $[4,5]$.

Безумовно фінансовий аспект даного питання $є$ значно ширшим і охоплює не лише матеріальну сторону оборотних активів. Тут аналізуються оборотні фонди і фонди обігу. Основними показниками при цьому виступають ліквідність балансу, платоспроможність, коефіцієнт забезпеченості власними оборотними засобами, коефріцієнт стійкості економічного росту тощо. Ці показники доповнюються коефіцієнтом оборотності, завантаження і тривалості обороту.

Ми пропонуємо своє бачення розкриття даного питання і уніфріковану систему показників в контексті дослідження макрорівневої сукупності в умовах сьогодення.

Мета.

Акцентовано увагу на процедурі аналізу оборотних активів на рівні Хмельницької області. Зазначено методичні етапи та запропоновано систему показників, які $€$ доречними в умовах сьогодення.

Для розкриття поставленої мети необхідно вирішити такі завдання:

- Проаналізувати дослідний об'єкт та визначитися з його спеціалізацією;

- Дослідити динаміку, структуру оборотних активів та зміни, що в ній відбулися;

- Вивчити питання співвідношення окремих складових активу балансу та вплив їх рівня на ефективність господарювання;

- Розкрити питання джерел формування оборотних активів та їх структурних співвідношень;

- Розрахувати показники рівня та ефективності використання оборотних активів, встановити причинно-наслідкові зв'язки і залежності між чинниками формування та результатом на 
базі проведеного факторного аналізу.

\section{Методологія дослідження.}

В основу методології нашого дослідження покладено різноманітні загальнонаукові, статистичні та конкретно економічні методи і прийоми. Так, для вивчення динамічного ряду випуску продукції, оборотних активів та джерел їх формування задіяні прийоми рядів динаміки, відносних величин, порівняння, аналізу і синтезу тощо. За допомогою графічного методу вдалося проаналізувати структуру випуску продукції, джерел формування оборотних активів та вияснити домінанти в даному питанні. Прийоми елімінування дозволили вивчити причинно-наслідкові зв'язки і залежності між факторами формування та ефективності використання оборотних активів. Скориставшись способами перетворення детермінованих кратних моделей вдалося створити нову модель, з новими чинниками, і з іншого боку підійти до аналізу результативної ознаки.

\section{Результати.}

Хмельницька область розташована в західній частині Правобережжя України. Чисельність наявного населення станом на 1 січня 2018 року становило 1274,4 тис. чоловік. Територія області займає 20,6 км², а протяжність із заходу на схід - 192,5 км та з півночі на південь - 256,2 км.

Крайніми точками на півночі являються с. Веселинівка Славутського району, на півдні с.Гринчук Кам'янець-Подільського району, на заході - околиці с.В'язовець Білогірського району та с.Мислова Волочиського району, на сході - с.Вівсяники Деражнянського району.

Суміжними областями є Житомирська, Рівненська, Тернопільська, Чернівецька, Вінницька.

До складу області входять 20 районів, 13 міст, у тому числі 6 - обласного значення, 24 селища міського типу та 1414 сільських населених пунктів.

Питома вага області в економіці України 2017 р. становила по кількості населення - 3\%, виробництву промислової продукції майже 20\%. Причому деякі види продукції машинободування становили 91,8\%, виробництво одягу, шкіри, виробів зі шкіри та інших матеріалів коливалося від 5 до $74 \%$.

Областю вироблялося 5,6\% продукції сільського господарства України, а розмір інвестицій в неї становив 2,3\% [13].

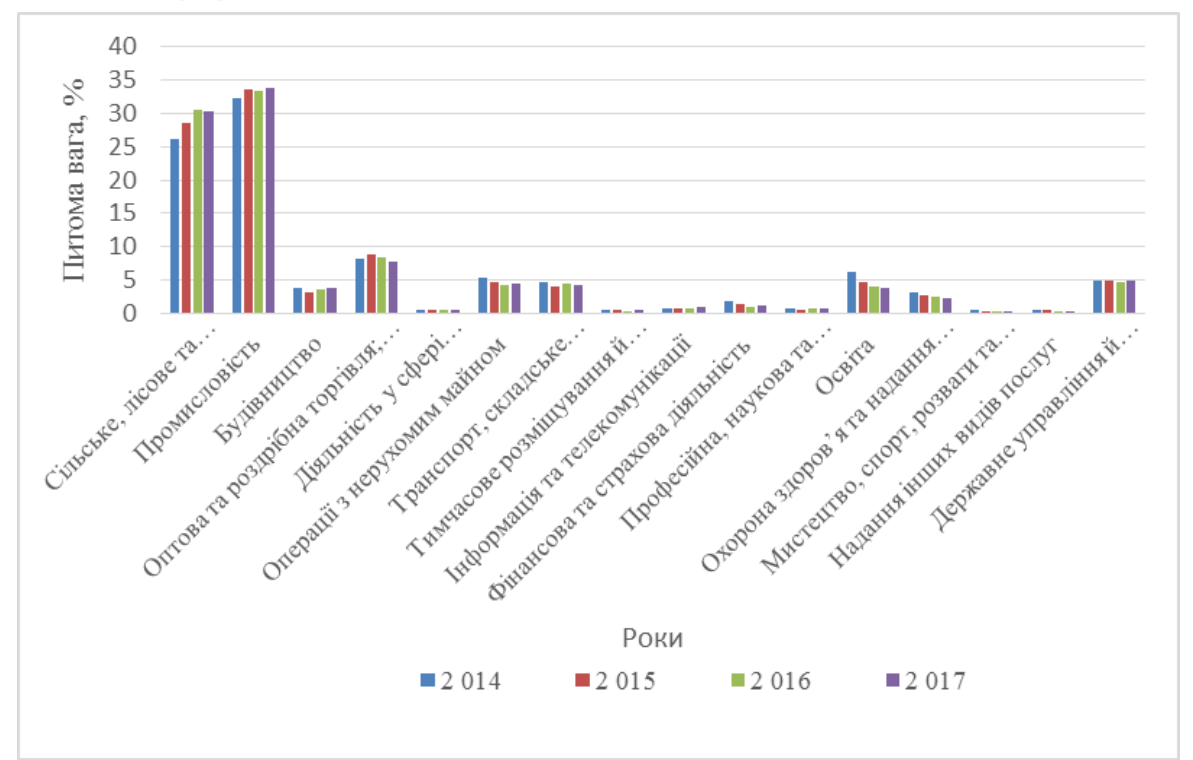

Рис. 1. Структура випуску продукції Хмельниччиною в основних цінах, \% Джерело: систематизовано на основі статистичного щорічника Хмельницької області 
Ключовими галузями Хмельниччини, за даними рис. $1 €$ промисловість та сільське, лісове і рибне господарство. В структурі випуску продукції Хмельниччини 2017 р. перша займала понад 30\%, а друга -33\%. Інші види продукції мали досить несуттєву питому вагу. Так, від 7 до 9\%, за аналізований період займали оптова, роздрібна торгівлі та ремонт автотранспортних засобів і мотоциклів. Від 3 до 6\% припадало на будівництво, освіту, операції з нерухомим майном, транспорт, складське господарство, пошту та кур'єрську діяльність. В цей ж діапазон входять державне управління та оборона. Інші види економічної діяльності склали менше трьох відсотків у структурі випуску продукції Хмельницькою областю.

За видами економічної діяльності проаналізуємо і динаміку оборотних активів. Останнє дозволило підкреслити спеціалізацію досліджуваної сукупності.

Таблиця 1. Динаміка оборотних активів Хмельниччини за видами економічної діяльності, млн. грн.

\begin{tabular}{|l|c|c|c|c|c|c|}
\hline \multicolumn{1}{|c|}{ Види економічної діяльності } & $2013 p$. & $2014 p$. & $2015 p$. & $2016 p$. & $2017 p$. & $\begin{array}{c}2017 p . y \\
\% \text { до } \\
2013 p .\end{array}$ \\
\hline Усього & 25384,8 & 30785,8 & 56365,5 & 247246,4 & 70155,3 & 276,4 \\
\hline $\begin{array}{l}\text { Сільське, лісове та рибне } \\
\text { господарство }\end{array}$ & 9179,3 & 12891,4 & 33370,6 & 192559,7 & 29749,3 & 324,1 \\
\hline Промисловість & 6414,2 & 8501,8 & 10762,5 & 13577,2 & 16769,6 & 261,4 \\
\hline Будівництво & 1554,4 & 1450,1 & 1646,5 & 1774,5 & 2577,8 & 165,8 \\
\hline $\begin{array}{l}\text { Оптова та роздрібна торгівля; } \\
\text { ремонт автотранспортних засобів і } \\
\text { мотоциклів }\end{array}$ & 5559,2 & 5368,6 & 8386,4 & 36652,1 & 17217,8 & 309,7 \\
\hline $\begin{array}{l}\text { Діяльність у сфері } \\
\text { адміністративного та допоміжного } \\
\text { обслуговування }\end{array}$ & 438,1 & 215 & 158,3 & 241,6 & 383,6 & 87,6 \\
\hline Операції з нерухомим майном & 936,9 & 1015,1 & 980,2 & 1268,4 & 1624,1 & 173,3 \\
\hline $\begin{array}{l}\text { Транспорт, складське господарство, } \\
\text { поштова та кур'єрська діяльність }\end{array}$ & 945,8 & 988,2 & 647,5 & 785,7 & 1260,2 & 133,2 \\
\hline $\begin{array}{l}\text { Тимчасове розміщування й } \\
\text { організація харчування }\end{array}$ & 28,9 & 28,0 & 38,6 & 33,8 & 46,0 & 159,2 \\
\hline Інформація та телекомунікації & 58,9 & 52,5 & 61,8 & 66,1 & 88,2 & 149,7 \\
\hline Фінансова та страхова діяльність & 125,8 & 120,6 & 153,1 & 100,8 & 103,0 & 81,9 \\
\hline $\begin{array}{l}\text { Професійна, наукова та технічна } \\
\text { діяльність }\end{array}$ & 114,7 & 119,5 & 117,7 & 138,6 & 274,0 & 238,9 \\
\hline Освіта & 2,7 & 2,0 & 3,1 & 5,7 & 7,0 & 259,3 \\
\hline $\begin{array}{l}\text { Охорона здоров'я та надання } \\
\text { соціальної допомоги }\end{array}$ & 15,5 & 12,3 & 12,5 & 19,4 & 21,8 & 140,6 \\
\hline $\begin{array}{l}\text { Мистецтво, спорт, розваги та } \\
\text { відпочинок }\end{array}$ & 1,3 & 1,2 & 2,7 & 0,3 & 8,3 & 638,5 \\
\hline Надання інших видів послуг & 9,4 & 19,6 & 23,8 & 22,6 & 24,6 & 261,7 \\
\hline
\end{tabular}

Джерело: систематизовано на основі статистичного щорічника Хмельницької області

У вартісних величинах досліджуваної сукупності найбільше 2017 р. (таблиця 1) займали оборотні активи сільського, лісового і рибного господарства (29749,3 млн. грн.), оптової, роздрібної торгівлі, ремонту автотранспортних засобів і мотоциклів (17217,8 млн. грн.) та промисловості 16769,6 млн. грн. Базисного року спостерігаємо трохи іншу картину. Домінантом тут виступало знову ж таки сільського, лісового і рибного господарства, на друге місце перемістилася промисловість, а на третьому зосередилися оптова, роздрібна торгівлі, ремонт автотранспортних засобів і мотоциклів. Якщо взяти середнє значення за п'ять років, то повторюється картина 2017 року.

За проведеними дослідженнями робимо висновок, що основна маса оборотних активів належить видам економічної діяльності, на яких спеціалізується дослідний об'єкт.

Структурні співвідношення в балансі підприємств, їх аналіз дозволили скоригувати вартісні 
величини, направити їх в більш оптимальне русло і тим самим підвищити ефеективність їх використання. [15] В проведених дослідження ми зупинилися на питомій вазі оборотних активів в структурі балансу і дослідили вплив даного фактору на ефективність роботи досліджуваної сукупності.

\section{Таблиця 2. Питома вага оборотних активів в структурі балансу підприємств Хмельниччини} за видами економічної діяльності, \%

\begin{tabular}{|c|c|c|c|c|c|c|}
\hline Види економічної діяльності & $2013 p$. & $2014 p$. & $2015 p$. & $2016 p$. & $2017 p$. & $\begin{array}{c}\text { Відхилення } \\
\text { 2017р. від } \\
\text { 2013р., \% } \\
\end{array}$ \\
\hline $\begin{array}{l}\text { Усього (в середньому за видами } \\
\text { економічної діяльності) }\end{array}$ & 50,3 & 52,7 & 67,4 & 88,6 & 63,7 & 13,4 \\
\hline $\begin{array}{l}\text { Сільське, лісове та рибне } \\
\text { господарство }\end{array}$ & 55,5 & 59,2 & 85,8 & 96,4 & 74,6 & 19,1 \\
\hline Промисловість & 41,3 & 46,8 & 48,5 & 51,9 & 51,4 & 10,1 \\
\hline Будівництво & 73,9 & 66,0 & 67,9 & 70,1 & 71,7 & $-2,2$ \\
\hline $\begin{array}{l}\text { Оптова та роздрібна торгівля; } \\
\text { ремонт автотранспортних засобів і } \\
\text { мотоциклів }\end{array}$ & 86,0 & 85,2 & 89,1 & 95,2 & 91,0 & 5 \\
\hline $\begin{array}{l}\text { Діяльність у сфері } \\
\text { адміністративного та допоміжного } \\
\text { обслуговування }\end{array}$ & 9,8 & 4,9 & 3,0 & 4,2 & 6,0 & $-3,8$ \\
\hline Операції з нерухомим майном & 30,8 & 32,6 & 30,8 & 33,2 & 31,7 & 0,9 \\
\hline $\begin{array}{l}\text { Транспорт, складське } \\
\text { господарство, поштова та } \\
\text { кур'єрська діяльність }\end{array}$ & 59,7 & 60,5 & 47,0 & 46,2 & 49,9 & $-9,8$ \\
\hline $\begin{array}{l}\text { Тимчасове розміщування й } \\
\text { організація харчування }\end{array}$ & 21,9 & 23,8 & 28,6 & 27,7 & 34,4 & 12,5 \\
\hline Інформація та телекомунікації & 70,1 & 66,2 & 66,7 & 67,0 & 65,2 & $-4,9$ \\
\hline Фінансова та страхова діяльність & 63,2 & 62,2 & 53,9 & 47,1 & 44,4 & $-18,8$ \\
\hline $\begin{array}{l}\text { Професійна, наукова та технічна } \\
\text { діяльність }\end{array}$ & 51,0 & 49,5 & 44,2 & 50,3 & 60,9 & 9,9 \\
\hline Освіта & 35,8 & 26,5 & 31,2 & 41,7 & 43,5 & 7,7 \\
\hline $\begin{array}{l}\text { Охорона здоров'я та надання } \\
\text { соціальної допомоги }\end{array}$ & 26,2 & 20,2 & 19,7 & 25,4 & 31,4 & 5,2 \\
\hline $\begin{array}{l}\text { Мистецтво, спорт, розваги та } \\
\text { відпочинок }\end{array}$ & 44,1 & 43,3 & 35,8 & 10,4 & 27,1 & -17 \\
\hline Надання інших видів послуг & 17,1 & 31,0 & 43,0 & 42,3 & 43,7 & 26,6 \\
\hline
\end{tabular}

Джерело: систематизовано на основі статистичного щорічника Хмельницької області

Проаналізувавши таблицю 2 робимо висновок, що в структурі балансу підприємств питома вага оборотних активів в динаміці збільшилася на 13,4\%, а порівняно з попереднім роком зросла на $24,9 \%$ і звітного року становила $63,7 \%$.

Найвищий рівень даного показника в середньому за видами економічної діяльності спостерігали 2016 р. - 88,6\%, а найнижчий 2013 р. - 50,3\%. Останнє зумовлено високим рівнем аналогічного показника по сільському, лісовому та рибному господарству. Питома вага саме цього виду діяльності в структурі балансу підприємств Хмельниччини домінує.

Друге і третє місця за видами економічної діяльності в різні роки зайняли промисловість та оптова, роздрібна торгівлі і ремонт автотранспортних засобів та мотоциклів. За питомою вагою оборотних активів в структурі балансу саме цих видів економічної діяльності маємо таку ж саму картину, як і по сільському, лісовому та рибному господарству.

Тобто три вище зазначених види економічної діяльності $€$ ключовими в економіці Хмельниччини. Як наслідок, вони вплинули на структуру балансу і зміни, що в ньому відбулися.

Наступним етапом аналізу $є$ вивчення джерел формування оборотних активів. Більшість науковців їх об'єднують у три групи - власні джерела, прирівняні до власних і позичені джерела. Особливість деяких дослідників полягає в тому, що до групи позичених джерел вони включають 
довгострокові кредити банків. (Ярошевич Н. Б.) Ми згодні з даним моментом і, як наслідок, включаємо дану складову у наші дослідження.

Таблиця 3. Динаміка джерела формування оборотних активів Хмельниччини, млн. грн.

\begin{tabular}{|l|c|c|c|c|c|c|}
\hline \multicolumn{1}{|c|}{ Види джерел } & 2013p. & $2014 \mathrm{p}$. & $2015 \mathrm{p}$. & $2016 \mathrm{p}$. & $2017 \mathrm{p.}$ & $\begin{array}{c}2017 \mathrm{p} . \mathrm{y} \\
\% \text { до } \\
2013 p .\end{array}$ \\
\hline Власний капітал & 19642 & 16894 & 15063 & 18213 & 22678 & 115 \\
\hline $\begin{array}{l}\text { Довгострокові } \\
\text { зобов'язання } \\
\text { забезпечення }\end{array}$ & 10564 & 16790 & 18009 & 18629 & 24397 & 231 \\
\hline $\begin{array}{l}\text { Поточні зобов'язання } \\
\text { і забезпечення }\end{array}$ & 20280 & 24675 & 50571 & 242248 & 63144 & 311 \\
\hline Разом джерел & 50486 & 58359 & 83643 & 279090 & 110219 & 218 \\
\hline
\end{tabular}

Джерело: систематизовано на основі статистичного щорічника Хмельницької області

Вартість джерел фінансування активів Досліджуваної області зросла у 2,2 рази і звітного року становила 110219 млн. грн. Дана величина порівняно з попереднім роком є значно меншою. Причому їх відношення становило 40\%. Тобто 2016 р. джерел оновлення активів використано на $60 \%$ більше ніж 2017p. Варто відмітити і той момент, що 2016 р. за розміром джерел суттєво домінував над 2013-2015 pр.

Як показав проведений аналіз збільшення розміру джерел формування активів 2016 р. дозволило вивести Хмельниччину на позитив по фінансових результатах. Доказом цього $€$ їх абсолютні величині. Рівень останніх 2014-2015pр. мали значення із знаком мінус, а 2016-2017pp. із знаком плюс. Так, 2016 і 2017 рр. досліджувана область отримала, відповідно, 3005,9 і 1846,2 млн. грн. прибутку.

У зв'язку з тим, що даний фактор мав вирішальний вплив на формування фінансових результатів необхідно його більш детально вивчити. Це можливо зробити проаналізувавши структуру джерел і зміни, що в ній відбулися.

Таблиця 4. Динаміка структури джерел формування оборотних активів Хмельниччини

\begin{tabular}{|c|c|c|c|c|c|c|c|c|c|}
\hline \multirow{2}{*}{ Види джерел } & \multirow{2}{*}{$2013 p}$. & \multirow{2}{*}{$2014 p}$. & \multirow{2}{*}{$2015 p}$. & \multirow{2}{*}{$2016 p}$. & \multirow{2}{*}{$2017 p}$. & \multicolumn{2}{|c|}{$\begin{array}{c}\text { Відхилення 2017p. } \\
\text { від }\end{array}$} & \multicolumn{2}{|c|}{$\begin{array}{l}\text { Відхилення } \\
2016 \text { р. від }\end{array}$} \\
\hline & & & & & & $2013 p$. & $2016 p$. & $2015 p$. & $2013 p$. \\
\hline Власний капітал & 38,9 & 28,9 & 18,0 & 6,5 & 20,6 & $-18,3$ & 14,1 & $-11,5$ & $-32,4$ \\
\hline $\begin{array}{l}\text { Довгострокові } \\
\text { зобов'язання } \\
\text { забезпечення }\end{array}$ & 20,9 & 28,8 & 21,5 & 6,7 & 22,1 & 1,2 & 15,4 & $-14,8$ & $-14,2$ \\
\hline $\begin{array}{l}\text { Поточні } \\
\text { зобов'язання } \\
\text { забезпечення }\end{array}$ & 40,2 & 42,3 & 60,5 & 86,8 & 57,3 & 17,1 & $-29,5$ & 26,3 & 46,6 \\
\hline Разом джерел & 100 & 100 & 100 & 100 & 100 & 0 & 0 & 0 & 0 \\
\hline
\end{tabular}

Джерело: систематизовано на основі статистичного щорічника Хмельницької області

Дані таблиці 4 свідчать про те, що саме 2016 р. по структурним співвідношенням відрізняється від інших років. Так, тут домінують поточні зобов'язання і забезпечення. Їх питома вага саме цього року досягала 86,8\%. Власний капітал за питомою вагою 2016 р. займав 6,5\%, а довгострокові зобов'язання і забезпечення - 6,7\%. Вище зазначені величини суттєво відрізняються від даних 2013-2015 та 2017 рр. і по суті були "винятком, а не правилом". Як наслідок, досліджувати якісну сторону оборотних активів (в розрізі видів економічної діяльності) доцільно, все ж таки, на базі років, де не відбувалося стрибків, щоб бачити реальний стан справ.

В таблиці 5 представлено розподіл основних джерел формування активів в контексті видів економічної діяльності, а на рис. 2 ми запропонували види економічної діяльності і за якими джерелами формуються їх активи у відсотковому співвідношенні. 
Таблиця 5. Структура джерел формування оборотних активів в розрізі видів економічної діяльності Хмельниччини 2017 р.

\begin{tabular}{|c|c|c|c|c|}
\hline \multirow[t]{2}{*}{ Види економічної діяльності } & \multicolumn{4}{|c|}{ Джерела формування оборотних активів } \\
\hline & $\begin{array}{c}\text { Власний } \\
\text { капітал }\end{array}$ & $\begin{array}{l}\text { Довгострокові } \\
\text { зобов'язання і } \\
\text { забезпечення }\end{array}$ & $\begin{array}{c}\text { Поточні } \\
\text { зобов'язання і } \\
\text { забезпечення }\end{array}$ & $\begin{array}{c}\text { Разом } \\
\text { джерел (в } \\
\text { середньому) }\end{array}$ \\
\hline Усього & 100 & 100 & 100 & 100 \\
\hline Сільське, лісове та рибне господарство & 57,60 & 9,08 & 38,97 & 36,19 \\
\hline Промисловість & 5,86 & 55,83 & 28,02 & 29,62 \\
\hline Будівництво & 2,88 & 1,50 & 4,08 & 3,26 \\
\hline $\begin{array}{l}\text { Оптова та роздрібна торгівля; ремонт } \\
\text { автотранспортних засобів і мотоциклів }\end{array}$ & 6,86 & 21,96 & 19,01 & 17,16 \\
\hline $\begin{array}{l}\text { Діяльність у сфері адміністративного та } \\
\text { допоміжного обслуговування }\end{array}$ & 25,98 & 0,25 & 0,72 & 5,82 \\
\hline Операції з нерухомим майном & $-3,28$ & 10,25 & 5,33 & 4,65 \\
\hline $\begin{array}{l}\text { Транспорт, складське господарство, } \\
\text { поштова та кур'єрська діяльність }\end{array}$ & 2,33 & 0,46 & 2,98 & 2,29 \\
\hline $\begin{array}{l}\text { Тимчасове розміщування й } \\
\text { організація харчування }\end{array}$ & 0,46 & 0,01 & 0,04 & 0,12 \\
\hline Інформація та телекомунікації & 0,37 & 0,00 & 0,08 & 0,12 \\
\hline Фінансова та страхова діяльність & 0,49 & 0,11 & 0,15 & 0,21 \\
\hline $\begin{array}{l}\text { Професійна, наукова та технічна } \\
\text { діяльність }\end{array}$ & $-0,08$ & 0,55 & 0,53 & 0,41 \\
\hline Освіта & 0,05 & 0,00 & 0,01 & 0,01 \\
\hline $\begin{array}{l}\text { Охорона здоров'я та надання } \\
\text { соціальної допомоги }\end{array}$ & 0,19 & 0,01 & 0,04 & 0,06 \\
\hline $\begin{array}{l}\text { Мистецтво, спорт, розваги та } \\
\text { відпочинок }\end{array}$ & 0,12 & 0,00 & 0,00 & 0,03 \\
\hline Надання інших видів послуг & 0,16 & 0,00 & 0,03 & 0,05 \\
\hline
\end{tabular}

Джерело: розраховано на основі даних статистичного щорічника Хмельницької області

За даними таблиці 5 джерела формування активів Хмельниччини розподіляються так: 36\% відводилося на сільське, лісове та рибне господарство, майже 30\% - на промисловість, 17,2\% - на оптову, роздрібну торгівлі, ремонт автотранспортних засобів і мотоциклів, 5,8 \% - на діяльність у сфрері адміністративного і допоміжного обслуговування, інші види економічної діяльності менше $5 \%$. Ця інформація підкреслює спеціалізацію області і вказує на те, що саме ці види економічної діяльності є найбільш ресурсозатратними для неї.

Найбільш незалежним від зовнішніх джерел формування активів $€$ сільське, лісове і рибне господарство. Питома вага власного капіталу, що йому належало у структурі власного капіталу області 2017 р. становила - 57,5\%. Друге місце тут займала діяльність у сфері адміністративного та допоміжного обслуговування з питомою вагою майже $26 \%$, а третє посідала промисловість 3 $5,86 \%$ структури власного капіталу.

Найбільша частка довгострокових зобов'язань і забезпечень зосередилося у промисловості (55,83\%), а поточних зобов'язань і забезпечень розподілилася між видами економічної діяльності відповідно до спеціалізації аналізованої області.

За інформацією представленою на рис. 2 ми можемо зробити висновок, що діяльність Хмельниччини в основному залежить від короткострокових зобов'язань на $57 \%$, а довгострокових на $22 \%$. Власним капіталом досліджувана область в середньому за всіма видами економічної діяльності забезпечена на 20,6\%.

В розрізі видів економічної діяльності найбільш незалежними $€$ діяльність у ссрері адміністративного та допоміжного обслуговування (91,9\% джерел $€$ власними) мистецтво, спорт, розваги та відпочинок (90\%), тимчасове розміщування й організація харчування $(78,4 \%)$, освіта $(73,6 \%)$ та надання інших видів послуг $(66,5 \%)$. 


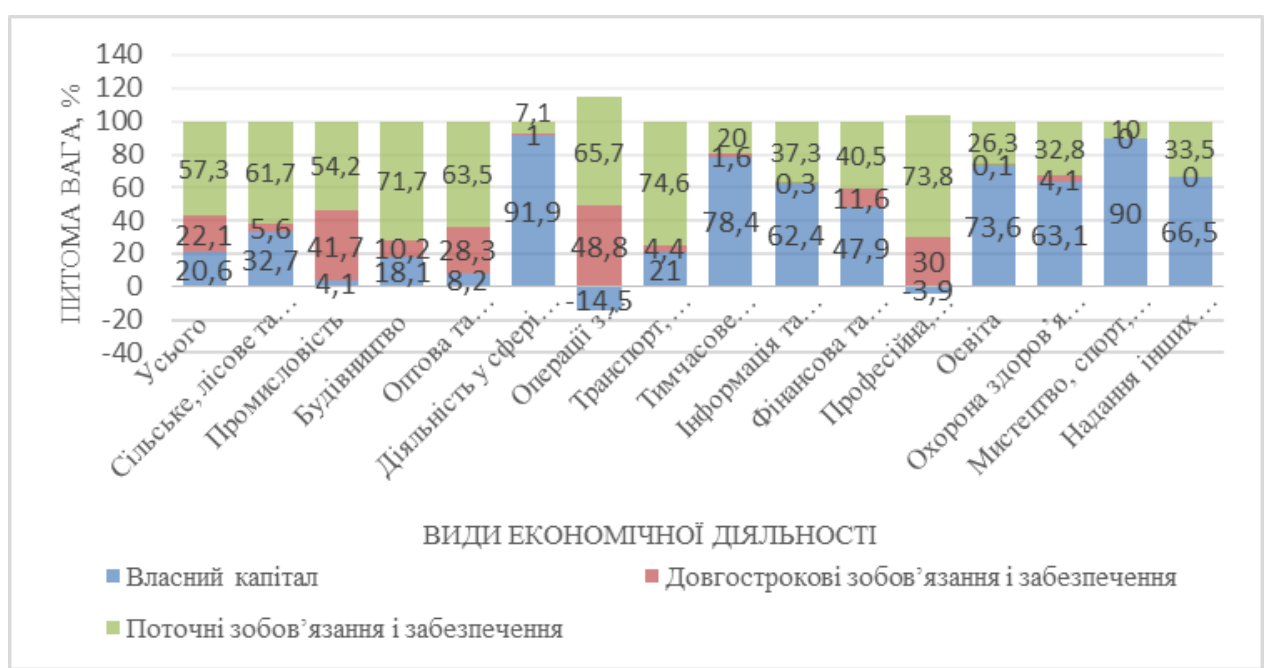

\section{Рис. 2. Питома вага джерел формування оборотних активів за видами економічної діяльності Хмельниччини 2017 р.}

Джерело: розраховано на основі даних статистичного щорічника Хмельницької області

Ключові види економічної діяльності Хмельниччини більш залежні від зовнішніх джерел. Так, сільське, лісове і рибне господарство на 32,7\% забезпечене власними джерелами формування активів, а промисловість - лише на $4 \%$. Але це не заважає їм ефективно працювати і отримувати позитивні фінансові результати. Останнє свідчить про те, що розмір капіталу має відносний вплив на ефрективність роботи суб'єкта господарювання. А ось інтенсивність його залучення, своєчасність надходження і якість складових безумовно впливають на кінцевий результат. Побачити це можливо проаналізувавши показники таблиці 6.

Таблиця 6. Показники рівня та ефективності використання оборотних активів

\begin{tabular}{|l|c|c|c|c|c|c|}
\hline \multicolumn{1}{|c|}{ Види економічної діяльності } & $2013 p$. & $2014 p$. & $2015 p$. & $2016 p$. & $2017 p$. & $\begin{array}{c}\text { Відхилення } \\
2017 p . \text { від } \\
2013 p ., \%\end{array}$ \\
\hline $\begin{array}{l}\text { Коефіцієнт забезпеченості власними } \\
\text { оборотними засобами }\end{array}$ & $-0,21$ & $-0,35$ & $-0,22$ & $-0,05$ & $-0,25$ & $-0,03$ \\
\hline Коефіцієнт оборотності оборотних активів & 1,38 & 1,38 & 1,02 & 0,27 & 1,28 & $-0,10$ \\
\hline $\begin{array}{l}\text { Коефіцієнт оборотності власних оборотних } \\
\text { активів }\end{array}$ & $-0,16$ & $-0,25$ & $-0,21$ & $-0,20$ & $-0,19$ & $-0,04$ \\
\hline $\begin{array}{l}\text { Коефіцієнт завантаження оборотних } \\
\text { активів }\end{array}$ & 0,73 & 0,73 & 0,98 & 3,71 & 0,78 & 0,06 \\
\hline $\begin{array}{l}\text { Тривалість одного обороту оборотних } \\
\text { активів, днів }\end{array}$ & 261,78 & 261,71 & 352,29 & 1336,09 & 282,14 & 20,36 \\
\hline $\begin{array}{l}\text { Розмір вивільнення (залучення) оборотних } \\
\text { активів }\end{array}$ & 0,00 & 8,58 & $-14492,91$ & $-182055,04$ & 262065,80 & 262065,80 \\
\hline $\begin{array}{l}\text { Фондовіддача в розрахунку на 1 грн. } \\
\text { оборотних активів }\end{array}$ & 1,04 & 1,04 & 0,73 & 0,20 & 0,76 & $-0,28$ \\
\hline Фондомісткість & 0,96 & 0,96 & 1,37 & 5,06 & 1,32 & 0,36 \\
\hline Прибутковість оборотних активів & 0,02 & $-0,11$ & $-0,01$ & 0,01 & 0,03 & 0,00 \\
\hline Коефіцієнт стійкості економічного росту & 0,03 & $-0,20$ & $-0,03$ & 0,17 & 0,08 & 0,05 \\
\hline Поточний коефіцієнт платоспроможності & 1,25 & 1,25 & 1,11 & 1,02 & 1,11 & $-0,14$ \\
\hline
\end{tabular}
Джерело: розраховано на основі даних статистичного щорічника Хмельницької області 
До показників рівня використання оборотних активів відносять коефіцієнти оборотності, завантаження та тривалості одного обороту. Їх величина в динаміці була не стабільною. Так, звітного року коефіцієнт оборотності становив 1,28 , що порівняно з базисним менше на 0,1 , а 3 попереднім більше на 1,01 . Коефіцієнт завантаження $€$ зворотнім до оборотності, тому його величина в динаміці зросла на 0,06, а порівняно з попереднім роком зменшилася на 2,93.

Найнижче значення коефріцієнта оборотності спостерігаємо 2016 р. Останнє пов'язано із суттєвими вкладення в оборотні активи, тому за рік вони спроміглися пройти лише 0,27 циклу, тоді як звітного - більше одного циклу обігу. Підтвердженням вище зазначеного $є$ тривалість одного обороту у днях. Вона за нашими розрахунками 2016 р. становила 1336,1, а 2017 р. - 282,1 дня. Різницю самі бачимо і вона є суттєвою.

Показник, який свідчить про нестачу або надлишок оборотних активів і про те, скільки їх потрібно вивільнити (залучити) також порахований і проаналізований. Його величина свідчить про те, що 2015 і 2016 рр. маємо надлишок оборотних активів, а 2017 р. - нестачу порівняно 3 попереднім роком.

Фондовіддача у час пікового вкладення у оборотні активи - 2016 р. була мінімальною $(0,2)$, а 2017 р. збільшилася на 0,56 і становила 0,76.

Останнє свідчить про те, що не завжди вкладення призводять до бажаного результату. Інколи потрібно зачекати. Але, тут найчастіше постає питання не кількості, а якості проведеної роботи, в даному випадку зроблених вкладень. Тому на даний момент потрібно звертати особливу увагу.

Показники прибутковості оборотних активів і коефріцієнт стійкості економічного росту свідчать про те, що не дарма були вкладення. Так як вони в 2016 і 2017 рр. мали значення із плюсом.

Факторний аналіз $є$ важливим моментом у справі вивчення причин зміни того чи іншого показника у динаміці. Його проводять на базі стохастичних і детермінованих моделей.

В основу перших закладено випадкові, ймовірні зв'язки і залежності, які можливо дослідити найчастіше за допомогою кореляційно-регресійного або дисперсійного аналізу.

В основі других (детермінованих) лежать функціональні зв'язки між досліджуваними елементами певної системи. В нашому прикладі ми зупинимося саме на них і розкриємо можливості їх практичної реалізації.

Так, детерміновані моделі можуть бути адитивними, мультиплікативними і кратними. Найчастіше у факторному аналізі використовуються другий і третій типи моделей або моделі змішаного типу. За багаторічним практичним досвідом нами зроблено висновок, що мультиплікативні моделі мають більшу пізнавальну значимість, ніж кратні, тому, як наслідок, до останніх застосовують 4 способи перетворення. Вони дозволяють здійснити зміни в моделі, які детально досліджують чисельник вихідної фракторної моделі (перший спосіб перетворення), знаменник вихідної фракторної моделі (другий спосіб перетворення), результативну ознаки (третій спосіб перетворення) і за четвертим способом перетворення створюють нову модель, що принципово відрізняється від діючої.

Вибрана нами кратна детермінована модель спонукає застосувати четвертий спосіб перетворення. Суть його полягає в тому, що чисельник і знаменник вихідної фракторної моделі ділять на один і той самий показник, тобто по суті скорочують на сталу величину. В результаті такого скорочення отримуємо якісно нову модель, яка дозволяє 3 іншого боку дослідити результативну ознаку.

Наприклад, початкова модель фондовіддачі включала співвідношення валового регіонального продукту і оборотних активів, а перетворена - річну продуктивність праці середньооблікового працівника та фондоозброєність оборотними активами середньооблікового працівника. 
Таблиця 7. Вплив річної продуктивності праці та рівня озброєності оборотними активами на ефективність використання оборотних активів

\begin{tabular}{|c|c|c|c|c|c|c|}
\hline Показники & $2013 p$. & $2014 p$. & $2015 p$. & $2016 p$. & $2017 p$. & $\begin{array}{c}\text { Відхилення } \\
\text { 2017р. від } \\
2013 \text { р., \% }\end{array}$ \\
\hline $\begin{array}{l}\text { Річна продуктивність праці } \\
\text { середньооблікового працівника, } \\
\text { грн. }\end{array}$ & 113,85 & 142,33 & 187,11 & 228,03 & 260,98 & 147,13 \\
\hline $\begin{array}{lr}\text { Озброєність } & \text { середньорічного } \\
\text { працівника } & \text { оборотними } \\
\text { активами, грн. } & \\
\end{array}$ & 109,37 & 136,24 & 256,68 & 1153,93 & 343,79 & 234,43 \\
\hline $\begin{array}{l}\text { Фондовіддача в розрахунку на } 1 \\
\text { грн. оборотних активів, грн. }\end{array}$ & 1,04 & 1,04 & 0,73 & 0,20 & 0,76 & $-0,28$ \\
\hline $\begin{array}{l}\text { Відхилення } \\
\text { загальне }\end{array}$ & - & 0,00 & $-0,32$ & $-0,53$ & 0,56 & $-0,28$ \\
\hline \multicolumn{7}{|l|}{ В т.ч. за рахунок зміни: } \\
\hline -річної продуктивності праці & - & 0,21 & 0,17 & 0,04 & 0,10 & 0,43 \\
\hline $\begin{array}{l}\text {-озброєності } \\
\text { активами }\end{array}$ & - & $-0,21$ & $-0,49$ & $-0,57$ & 0,47 & $-0,71$ \\
\hline
\end{tabular}

Джерело: розраховано на основі даних статистичного щорічника Хмельницької області

За результатами факторного аналізу фондовіддача оборотних активів зросла в динаміці внаслідок збільшення річної продуктивності праці. Ріст озброєності оборотними активами мав негативний вплив на кінцевий результат. Позитивний вплив даного фактору спостерігаємо у моделі, де базисним роком виступав 2016, а звітним - 2017 р.

\section{Висновки і перспективи.}

Проведені дослідження дозволяють зробити висновок, що аналіз оборотних активів на макрорівні має свої специфічні особливості. Вони скоріше за все стосуються не методики, а системи показників. Деякі ми порахувати не можемо, у зв'язку із браком інформації або вона пов'язана із комерційною таємницею, а деякі ми пропонуємо використати. Хоча науковці, які $з$ фінансової точки зору розкривають дане питання, їх не пропонують. Це стосується показників фондовіддачі і фондомісткості.

Методичні етапи особливостей аналізу оборотних активів на макрорівні в умовах сьогодення співпадають із поставленими завданнями, а саме - аналіз дослідного об'єкту та визначення його спеціалізації; дослідження динаміки, структури оборотних активів та змін, що в ній відбулися; вивчення питання співвідношення окремих складових активу балансу та вплив їх рівня на ефрективність господарювання; розкриття питання джерел формування оборотних активів та їх структурних співвідношень; розрахунок показників рівня та ефективності використання оборотних активів, встановлення причинно-наслідкових зв'язків і залежностей між чинниками формування та результатом на базі проведеного факторного аналізу.

Система показників, що нами використана - наявності, складу і структури оборотних активів та джерел їх фрормування, показники забезпеченості, рівня інтенсивності та ефективності використання оборотних активів.

\section{Список використаних джерел}

1. Причепа І. В., Руда Л. П. Економіка та організація виробництва. URL: https://web.posibnyky.vntu.edu.ua/fmib/35prychepa_ekonomika_ta_organizaciya_vyrobnictva/5.html

2. Нікіфорова Л. О. Економіка підприємства. Оборотні фонди та оборотні кошти підприємства. URL: https://web.posibnyky.vntu.edu.ua/fmib/24nikiforova_ekonomika_pidpriyemstva/p4.html

3. Дробишева О. О. Роль оборотних засобів у виробничому процесі підприємства. Економіка та управління підприємствами. 2016. Випуск 2 (02). URL: http://www.zgia.zp.ua/gazeta/evzdia_2016_2_19.pdf

4. Лаврова О. В. Економіка підприємства та маркетингу. Показники використання оборотних активів й 
їхній розрахунок. URL: https://buklib.net/books/37207/

5. Філімоненков О. С. Фінанси підприємств. Показники використання оборотних активів та їх розрахунок. URL: http://ecolib.com.ua/article.php?book=38\&article $=4520$

6. N. Kuprina, I. Chernenko. Current assets of the enterprise: theoretical and practical aspects. Food Industry Economics 10(1). URL:https://doi.org/10.15673/fie.v10i1.863

7. Купріянова Л.М., Болдирєв О.М. Оцінка ефективності управління дебіторською заборгованістю. Світ нової економіки. 2015. №2. URL: http://cyberleninka.ru/article/n/otsenkaeffektivnosti-upravleniya-debitorskoyzadolzhennostyu.

8. Рубаха М. В., Цюпа М. П. Прикладні аспекти аналізу оборотності капіталу суб'єкта господарювання. Ефективна економіка. 2017. №4. URL: http://www.economy.nayka.com.ua/?op=1\&z=5531

9. Шутько Г.М.,Рахімова Р.P. Управління дебіторською заборгованістю підприємства. SCI-ARTICLE. 2016. №1. URL: http://sci-article.ru/stat.php?i=1451314370

10. Власова Н. О., Чорна М. В., Михайлова О. В. та інші. Ефективність політики формування оборотних активів підприємств роздрібної торгівлі. Монографія. 2015. URL: http://elib.hduht.edu.ua/bitstream/123456789/121/1/CD\%2B\%D0\%BB\%D0\%BE\%D0\%BA.\%202015_\%D0\%9C\%D0\% BE\%D0\%BD\%D0\%BE\%D0\%B3\%D1\%80\%D0\%B0\%D1\%84\%D1\%96\%D1\%8F_\%20\%D0\%95\%D1\%84\%D0\%B5\%D 0\%BA\%D1\%82\%D0\%B8\%D0\%B2\%D0\%BD\%D1\%96\%D1\%81\%D1\%82\%D1\%8C\%20\%D0\%BF\%D0\%BE\%D0\%BB \%D1\%96\%D1\%82\%D0\%B8\%D0\%BA\%D0\%B8\%20\%D1\%84\%D0\%BE\%D1\%80\%D0\%BC\%D1\%83\%D0\%B2\%D0\% B0\%D0\%BD\%D0\%BD\%D1\%8F\%20\%D0\%BE\%D0\%B1\%D0\%BE\%D1\%80\%D0\%BE\%D1\%82\%D0\%BD\%D0\%B8\% D1\%85\%20\%D0\%B0\%D0\%BA\%D1\%82\%D0\%B8\%D0\%B2\%D1\%96\%D0\%B2...pdf

11. Соляник Л. Г., Дубєй Ю. В. Оборотні активи машинобудівних підприємств: процеси відтворення й оптимізації структури. Монограффія.

URL: http://ir.nmu.org.ua/bitstream/handle/123456789/146580/\%D0\%9C\%D0\%9E\%D0\%9D\%D0\%9E\%D0\%93\%D0\%A0\% D0\%90\%D0\%A4\%D0\%98\%D0\%AF\%20\%20\%D0\%A1\%D0\%9E\%D0\%9B\%D0\%AF\%D0\%9D\%D0\%98\%D0\%9A\%20 $\% 201$.pdf?sequence=1

12. Бурдейна Л. В. Теоретичні основи аналізу забезпеченості та ефективності використання виробничих запасів на підприємстві. Молодий вчений. 2015. №3 (18). URL: http://molodyvcheny.in.ua/files/journal/2015/3/07.pdf

13. Статистичний щорічник Хмельницької області за 2017 р. За редакцією начальника головного управління статистики у Хмельницькій області Л.О. Хамської. 2018. м. Хмельницький. 515с.

14. Budnyak L, Dobrovolska E. Key points of the analysis of capital investments. Scientific development and achievements: monograph. 2018. volume 1. P. 185-197.

URL: http://www.sciemcee.org/library/books/london/scientificdevelopmentandachievements/FLASH/index.html

Статтю отримано: 03.04.2019 / Рецензування 04.05.2019 / Прийнято до друку: 22.06.2019

\section{Budnyak Lyubov}

PhD in Economics, Docent

Department of Finance, Banking and Insurance

State Agrarian and Engineering University in Podilya

Kamianets-Podilskyi, Ukraine

E-mail: budnyakluba@gmail.com

\section{Dobrovolska Ella}

$\mathrm{PhD}$ in Economics, Docent

Department of Economics of Entrepreneurship, Trade and Stock Exchange activity

State Agrarian and Engineering University in Podilya

Kamianets-Podilskyi, Ukraine

E-mail: dobrovolskaella@gmail.com

\section{Dobrovolsky Mykola}

magistrant student

majors in finance, banking and insurance

State Agrarian and Engineering University in Podilya

Kamianets-Podilskyi, Ukraine

E-mail: budnyakluba@gmail.com 


\title{
PECULIARITIES OF ANALYSIS OF CURRENT ASSETS AT THE MACRO LEVEL IN THE PRESENT CONDITIONS
}

\begin{abstract}
In an unstable economy, timely provision of raw materials, materials, high quality, in the required volume, at an affordable price, and so on, is an important point for the continuous production process. All of these points relate to working capital, working capital, current assets. Therefore, their analysis helps to resolve many issues related to production efficiency, resource utilization, cost, and more.

This article focuses on the procedure of analysis of current assets at the level of Khmelnitsky region. Methodological steps are outlined and a system of indicators that are relevant in the current context is proposed.

Various general scientific, statistical and specifically economic methods and techniques were used to disclose the above. Thus, to study the dynamic series of output, current assets and sources of their formation involved techniques of series of dynamics, relative values, comparison, analysis and synthesis, etc. Using the graphical method, it was possible to analyze the structure of production, sources of formation of current assets and to clarify the dominant in this issue. The elimination techniques allowed us to study the cause and effect relationships and the relationships between the factors of formation and the efficiency of the use of current assets. Using the methods of transformation of deterministic multiple models, we were able to create a new model with new factors, and on the other hand to approach the analysis of the resultant trait.

The conducted studies allow us to conclude that the analysis of current assets at the macro level has its own specific features. Most likely, they are not about methodology but set of indicators. Some of us may not count due to a lack of information or trade secrets, and some we suggest using. Although scholars who financially disclose this issue, they do not offer. This applies to performance indicators and capital intensity.
\end{abstract}

Keywords: current assets, sources of formation, efficiency of use, factor analysis, causation, deterministic models.

\section{References}

1. Prichepa I. V., Ruda L. P. Ekonomika ta organizazia virobnitstva. Navchalnii posibnik. URL: https://web.posibnyky.vntu.edu.ua/fmib/35prychepa_ekonomika_ta_organizaciya_vyrobnictva/5.html

2. Nikiforova L. O. Ekonomika pidpriemstva. Oborotni fondi ta oborotni koshti pidpriemstva. URL: https://web.posibnyky.vntu.edu.ua/fmib/24nikiforova_ekonomika_pidpriyemstva/p4.html

3. Drobisheva O. O. Rol oborotnih zasobiv u virobnihomu prozesi pidpriemstva. Ekonomika ta upravlinia pidpriemstvami. 2016. Issue 2. URL: http://www.zgia.zp.ua/gazeta/evzdia_2016_2_19.pdf

4. Lavrova O. V. Ekonomika pidpriemstva ta marketingu. Pokazniki vikoristania oborotnih aktiviv I in rozrahunok. URL: https://buklib.net/books/37207/

5. Filimoninkov O. S. Finansi pidpriemstv. URL: http://ecolib.com.ua/article.php?book=38\&article $=4520$

6. N. Kuprina, I. Chernenko. Current assets of the enterprise: theoretical and practical aspects. Food Industry Economics 10(1). URL:https://doi.org/10.15673/fie.v10i1.863

7. Kuprianova L. M., Boldirev O. M. Ozinka efektivnosti upravlinia debitorskou zaborgovanistiu. Svit novoi ekonomiki . 2015. №2. URL: http://cyberleninka.ru/article/n/otsenkaeffektivnosti-upravleniya-debitorskoyzadolzhennostyu. (1.10.2018).

8. Rubaha M. V., Zjupa M. P. Prikladni aspekti analizu oborotnosti kapitalu subiektu gospodariuvania. Efektivna ekonomika. 2017. №4. URL: http://www.economy.nayka.com.ua/?op=1\&z=5531

9. Shutko G. M., Rahimova R. R. Upravlinia debitorskou zaborgovanistiu pidpriemstva. SCI-ARTICLE. 2016. №1. URL: http://sci-article.ru/stat.php?i=1451314370

10. Vlasovs N. O., Chorna M. V., Mihailova O. V. ta inshi. Efektivnist politiki formuvania oborotnih aktiviv pidpriemstv rozdribnoi torgilli. Monografiya. $2015 . \quad$ URL: http://elib.hduht.edu.ua/bitstream/123456789/121/1/CD\%2B\%D0\%BB\%D0\%BE\%D0\%BA.\%202015_\%D0\%9C\%D0\% BE\%D0\%BD\%D0\%BE\%D0\%B3\%D1\%80\%D0\%B0\%D1\%84\%D1\%96\%D1\%8F_\%20\%D0\%95\%D1\%84\%D0\%B5\%D 0\%BA\%D1\%82\%D0\%B8\%D0\%B2\%D0\%BD\%D1\%96\%D1\%81\%D1\%82\%D1\%8C\%20\%D0\%BF\%D0\%BE\%D0\%BB \%D1\%96\%D1\%82\%D0\%B8\%D0\%BA\%D0\%B8\%20\%D1\%84\%D0\%BE\%D1\%80\%D0\%BC\%D1\%83\%D0\%B2\%D0\% B0\%D0\%BD\%D0\%BD\%D1\%8F\%20\%D0\%BE\%D0\%B1\%D0\%BE\%D1\%80\%D0\%BE\%D1\%82\%D0\%BD\%D0\%B8\% D1\%85\%20\%D0\%B0\%D0\%BA\%D1\%82\%D0\%B8\%D0\%B2\%D1\%96\%D0\%B2...pdf

11. Solyanik L. G., Dubei Y. V. Oborotni aktivi mashinobudivnih pidpriemstv: prozesi vidtvorennya i optimizazii strukturi. Monografiya. URL: http://ir.nmu.org.ua/bitstream/handle/123456789/146580/\%D0\%9C\%D0\%9E\%D0\%9D\%D0\%9E\%D0\%93\%D0\%A0\% 
ІНСТИТУТ БУХГАЛТЕРСЬКОГО ОБЛІКУ, КОНТРОЛЬ ТА АНАЛІЗ В УМОВАХ ГЛОБАЛІЗАЦІї

Міжнародний науковий журнал. Випуск 1-2. 2019
THE INSTITUTE OF ACCOUNTING, CONTROL AND ANALYSIS IN THE GLOBALIZATION CIRCUMSTANCES International scientific journal. Issue 1-2. 2019

D0\%90\%D0\%A4\%D0\%98\%D0\%AF\%20\%20\%D0\%A1\%D0\%9E\%D0\%9B\%D0\%AF\%D0\%9D\%D0\%98\%D0\%9A\%20 $\% 201$.pdf?sequence=1

12. Burdeina L. V. Teoretichni osnovi analizu zabezpechenosti ta efektivnosti vikoristaniya virobnichih zapasiv. Molodii vhenii. 2015. №3 (18). URL: http://molodyvcheny.in.ua/files/journal/2015/3/07.pdf

13. Statistichnii shorichnik Hmelnitskoi oblasti za 2017 r. Za redakzieyu nachalnika golovnogo upravlinia statistiki u Hmelnitskii oblasti L. O. Hamskoi. 2018. 515 p.

14. Budnyak L, Dobrovolska E. Key points of the analysis of capital investments. Scientific development and 2018.

volume 1.

P. 185-197.

URL:

http://www.sciemcee.org/library/books/london/scientificdevelopmentandachievements/FLASH/index.html

Received: 04.03.2019 / Review 05.04.2018 / Accepted 06.22.2019

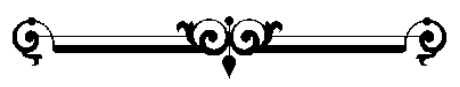

